conscience for the richer countries, particularly the United States.

\section{Aircraft for Aldabra?}

The Council of the Royal Society has taken the unusual step of making public its "considerable concern" about the future of Aldabra Island, in the Indian Ocean north of Madagascar. The immediate anxiety is that the British defence authorities are interested in the island as a possible air staging post in the Indian Ocean. In a statement published last week the council of the Royal Society says that Aldabra is the only island in the Indian Ocean which has remained "essentially unaffected by man", with the result that its flora and fauna contain many species not found elsewhere. Indeed, the island supports something like 10,000 of the land tortoise (T'estudo gigantea) which is now found in its natural state only on Aldabra and the Galapagos Islands. Among the notable sea-birds are frigates (Fregata minor and Fregata ariel iredalei) which are likely to be a hazard to aircraft if an airstrip is ever built. The land birds include a flightless rail (Dryolimnas cuvieri). Although frigate birds occur elsewhere in the Indian Ocean, Aldabra is the principal breeding ground for them as for the green turtle (Chelonia mydas) and the hawksbill turtle (Eretmochelys imbricata). It is also estimated that 10 per cent of the 170 plant species on the island do not grow elsewhere. There is little doubt that Aldabra is an isolated island ecosystem of unparalleled interest.

The interest of the Ministry of Defence stems from the recognition in the early sixties that a continued British presence East of Suez would require air staging posts in the Indian Ocean. The map of the Indian Ocean suggests that Aldabra Island would be valuable if Aden were untenable by the Royal Air Force. The Ministry of Defence says that other islands in the neighbourhood have been considered as staging posts, and says that it has promised the council of the Royal Society that the "scientific case for the preservation of Aldabra will be fully considered before a decision is made". The Ministry also says that if it should decide to make a staging post at Aldabra, it will do everything it can to protect the species living there, and that even though the frigate birds would be a hazard, there is no question of exterminating them. The trouble with this kind of assurance, of course, is that the experience of the nineteenth century, when the atolls of the Indian Ocean were widely exploited for their guano, coconuts and turtles, shows how little outside interference is necessary to disturb the balance of the ecosystem.

Aldabra is by all accounts an inhospitable place, which accounts for its isolation. At present the island supports a population of 80 to 100 migrant workers from the Seychelles. One of the particularly objectionable features of the proposal to build an airstrip is that this would have to be sited on the part of the atoll ring at present separated from the human settlement and which is also frequented by the land tortoises. Although the fact that the Royal Society has chosen to make its anxiety public is a sign that it is afraid of reading in the newspapers one day that Aldabra is to be an airstrip, relations with the Ministry of Defence are friendly enough for the Royal Navy to have agreed to ferry to the island in August this year the two scientists whose reports in 1966 drew attention to the dangers that an airfield would bring. It is now planned that a scientist should remain on the island at least until Easter 1968.

\section{Research into Environment}

Trw Centre for Environmental Studies has now been formally established as an independent charitable trust for advancing education and research in the planning and design of the physical environment. Announcing this in a written answer in the House of Commons on February 21, Minister of Housing and Local Government Mr. Anthony Greenwood, said that the Ford Foundation had given $\$ 750,000$ to the centre and, if Parliament approved, the Government intended to give a grant of one and a half times this amount for the first five years, up to a maximum of $f 600,000$. Eight members of the ten strong governing body had already been appointed; the Chairman would be Lord Llewelyn-Davies, and the Vice-Chairman Sir William Fiske. One international governor had been appointed in consultation with the Ford Foundation-Mr. M. Meyerson-and others who had accepted appointments as governors were Mr. C. D. Foster, Lord Holford, Lord Jellicoe, Mr. W. Taylor and Professor R. M. Titmuss. Dr. A. H. Chilver had been appointed Director of the Centre from April 1, 1967.

Lord Llewelyn-Davies said this week that the centre, based initially on London, would have three functions: discovering (by discussions and conferences) the areas in which research is needed, sponsoring research in universities, and interesting itself in information retrieval and dissemination. As well as architectural planning, it would hope to support research in economics, sociology and geography. There had, he said. been pressure to recognize this area of research, and the new centre was the result.

\section{University of Cranfield?}

THere may be an educational precedent of some importance in the way in which the College of Aeronautics at Cranfield has applied to the Privy Council for a charter that would allow it to award its own higher degrees in enginecring subjects. Discussions between the college and the Department of Education and Science have been going on ever since the Robbins Report recommended, in October 1963, that the college should be brought within the university system. At present the college is a direct pensioncr of the Department of Education and Science. Inquiries at the University Grants Committee and the Department of Education and Science suggest that it is not yet clear whether the granting of a charter will mean that the college is financed like the universities, through the University Grants Committee, or like the poly. technics, through the Department of Education and Science. It does, however, seem that the college has successfully resisted suggestions that it should accommodate itself under the wing of an existing university or, altcrnatively, that it should make use of the degrees being awarded by the National Council on Aoademic Awards. The way in which the college has becn pointing out that it lies a mere three miles from the site of the proposed city of Milton Keynes may indicate that 